\title{
Influence of organizational leadership on competitiveness of Public Universities in Kenya
}

\author{
Prof. R. W. Gakure, David M. Gichuhi, Dr. A. G. Waititu \\ (Jomo Kenyatta University of Agriculture and Technology, Kenya)
}

\begin{abstract}
The aim of the study was to determine the influence of organizational leadership on competitiveness of public universities in Kenya. Literature has revealed that the Kenyan and other African Universities are missing from the list of 100 best universities in the world and that most graduates coming from the continent are disadvantaged and less prepared to form the global labor force. The sample was $n=384$ including teaching and non teaching staff from public universities in Kenya. Factor analysis revealed four items with a loading value below 0.4 as recommended by David etal 2010, hence the items were eliminated in the analysis; all other remaining components were retained for analysis. The data had a Cronbach's alpha of 0.799; hence the instrument was determined to be reliable.Sekaran (2000) confirmed that the Cronbach Alpha measure above 0.70 indicates that the measurement instrument has the internal consistency. Data analysis revealed a positive relationship $R=0.403$, ( $p$-value $<0.05$ ) indicating a significant linear relationship between leadership and competitiveness.

Keywords: Leadership, Competitiveness, Kenyan Public Universities.
\end{abstract}

\section{Introduction}

It is through organized leadership that is democratic that an institution can be competitive, Kenyan Universities not being an exception. Yukl (2009) argued that quality of leadership is one of the most important determinants of meeting success in a tertiary institution. University or any institution cannot be competitive without good leadership (Ramsden, 1998).

Literature has shown that leadership skills are becoming increasingly important as a clear mechanism for step change in Universities especially in terms of innovation. Porter and Ketel (2003) highlight the important role that management and leadership play in determining individual business performance and productivity (Porter, 1998). Their report states that "more sophisticated company strategies require more highly skilled people and those companies must upgrade their operating practices and strategies if successful economic development is to occur and remain competitive. A competitive university must continually fuel its quality engine with people, capacity and resources (Lombardi, Craig, Capaldi, \& Gater, 2002).

This shows University leadership is integral in enhancing competitiveness. Competitiveness in Universities is embraced not only in Kenya but worldwide, where all nations' higher education functions as a social competition for status on a global platform. This status competition does not have to take a strictly economic form. No buyer-seller money need change hands for status competition to take place. This competition has a double aspect, in that students compete for prestigious educational opportunities, associated with social advantage. Universities compete for producer status, which is derived from educating the academic and social elite, from their research performance, and from staff reputation gained in research and scholarship. For a university to be competitive there should be a robust and proper leadership.

Lack of flexibility and innovativeness in the leadership in Universities mostly gives less room for competitiveness. Since the late nineteenth and the early twentieth century universities have changed considerably. Typically, these changes in higher education have reflected in the processes of managerial work. Rost (1993) argued that today's scholars discuss the basic nature of such leadership in terms of the "interaction" among the people involved in the process: both leaders and followers (Rost, November 1993).

\section{Research gap}

Studies; Ling and Jaw (2011) on leadership and competitiveness dealt with other organisations and not universities. Other studies; Spendlore (2007), Martinez (2001) looked at competencies of effective leadership in institutions of higher learning. None of the studies focused on leadership and competitiveness of Public Universities

\subsection{Factor analysis of leadership}

Factor Analysis was conducted to ascertain the suitability of all variables. According to David etal 2010, a factor loading of 0.4 or above is acceptable. 
On leadership four items with a loading of less than 0.4 were eliminated as shown below

Table 1.0 factor analysis for items on leadership

\begin{tabular}{ll}
\hline Component Matrix & Component 1 \\
\hline Leaders help employees under them accept responsibility for completing their work & .782 \\
Most workers get supportive communication from their leaders & .728 \\
In general employees are given room to make decisions concerning their areas of work & .713 \\
Leaders give effective orders and clarify procedures & .674 \\
Leaders give employees complete freedom to solve problems on their own & .656 \\
Leaders provide guidance without pressure to the subordinates & .622 \\
Most employees do not feel insecure about their work and need direction & .621 \\
As a rule, leaders allow employees to appraise their own work & .551 \\
Employee are part of decision making & .541 \\
Leaders stay out of the way of subordinates as they do their work & .532 \\
It is the leaders' responsibility to employees under them to help them find passion & .428 \\
The leader is the chief judge of the achievement of employees under him/her & .292 \\
In complex situations leaders let subordinates work problems out their own \\
As a rule employee are given punishment in order to motivate them achieve the university's objective \\
Employee are supervised closely to work effectively
\end{tabular}

Table 1.1 Leadership Reliability

Analysis Table 1.1 Reliability Analysis

\begin{tabular}{ll}
\hline Cronbach's Alpha & N of Items \\
.799 & 15 \\
\hline
\end{tabular}

\subsection{Descriptive statistics on Leadership}

Leadership was broken down into different areas and the key issues were examined to measure the kind of leadership exhibited by public universities in Kenya. Key items are discussed below and a summary given in table 1.2

Majority of the respondents (48.6\%) noted that employees are not involved in decision making while (32.3\%) agreed that they are involved.The outcome disagrees with Maile (2004) who notes that it is important to set up democratic structures, although it requires thoughtful planning. In a study by Oada, Gudo and Olel (2011) it was interpreted that inadequate involvement of staff and students in decision making impacted negatively on quality of teaching and learning in public universities and to some extent in private universities. Participative leaders involve their subordinates in making and implementing decisions (House, Hanges, Javidan, Dorfman, \& Gupta, 2004). They seek subordinates' input on important decisions and value others' points of view. Participative leaders also tend to be more tolerant of differences because they know that those differences can improve decision-making.In a study by Yukl, (2002) on leadership in organization, participative leadership can take different forms including consultation, joint decision making and delegation

The findings of this study indicated that the universities leadership does not involve employees in decision making.Bringing employees onboard when making decisions helps strengthen relationship with each employee as well as increasing their morale. This implies that universities leadership is not effective in motivating their employees.

Findings on employee guidance showed that $(43.1 \%)$ of the respondents suggested that leaders do not provide guidance to employees while $(39.0 \%)$ indicated that they do.The findings disagree with Sugarman's assertion that leadership in universities involves the process of influencing team members to work hard towards, and be committed to team goals, and that educational leaders can be either task-oriented or person-oriented (Sugarman, 2000). The findings are inconsistent with a study by Brown and Treviñ o, (2006) on a study on ethical leadership who found that ethical and empowering leader behaviors provide subordinates with important cues about the extent to which they can develop open and trusting relationships with their leader and such cues, in turn, may strengthen their emotional attachment to the work unit and modify their perception of leader effectiveness

Amabile, Schatzel, Moneta, and Kramer (2004), in a study on Leader's behaviors and thework environment for creativity assert that leader support behaviors should include both instrumental (task-oriented) and socio-emotional (relationship-oriented) actions. Leader's task support concerns maintaining or improving processes that facilitate the accomplishment of tasks, such a effective organizing of activities and resources, 
clarifying role expectations and standards for task performance, marshalling information, and solving problems. The findings imply that the failure by the leadership to model the way and encourage the employees would have a negative contribution to their success. Successful leadership inspire and encourage followers by showing the way.

The study established that $(48.9 \%)$ of respondents agreed that leaders offer subordinates supportive communication while (43.3\%) disagreed.The results agree with Kirkman and Rosen (1999) who found that feedback is likely to relate positively to the quality of exchange relationship between leaders and their subordinates, which in turn may enhance subordinate affective commitment. The findings of this study imply that the leadership in Kenyan Public universities creates effective commitment among employees through supportive communication. The variations in responses mean that the leadership needs to do much more in giving supportive communication to the subordinates

On leaders giving orders, $(47.2 \%)$ of the respondents agreed that leaders give effective orders while $(30.5 \%)$ suggested that they do not.The findings are in agreement with Sherman's assertions that a leader not only serves as a positive example to subordinates, but also must be able to convince them to follow orders. The orders must be given firmly, with expectations for them to be obeyed. But they must make sense to the subordinates, who will have the option of questioning, disobeying, resigning or obeying grudgingly (Sherman, 2007). In a study byNelda and Barroni (2001) itwas notedthatalthough organizational communication consists of issuing orders and giving instructions, to some extent, people must not think of leadership as "driving" employees to perform given tasks. In today's world, successful executives inspire, not force, their employees. The study findings indicated that leaders were found to be effective in terms of giving orders to the subordinates. Although majority of the respondents indicated that leaders give effective orders the variation in responses implies that more needs to be done to improve.

Majority (44.4\%) of the respondents disagreed that leaders stay out of the way of subordinates as they do their work while (35.4\%) indicate that they do. Considerable research suggests that empowering leaders try to enhance subordinate work motivation and performance through delegating authority for job-related decisions ( Kirkmanand Rosen, 1999; Yukl and Becker, 2006) and involving subordinates in making decisions about the work (Chen et al., 2011; Huang et al., 2010; Kirkman and Rosen, 1999; Konczak et al., 2000). Amabile et al. (2004) in a study on Leader behaviors and the work environment for creativity revealed that the leader of the unsuccessful team tended to over-control workers by issuing decrees and spending much time on checking performance and activities, even for their highly experienced workers. Excessive monitoring may have negative consequences for application behaviour as well. In a study by Oliver and Kandad (2006) onthe impact of empowering leadership, it was noted that empowered employees with a certain degree of autonomy in task achievement can provide a useful agility to the organization's knowledge culture, which then enables and motivates these same employees to attain knowledge management objectives. The findings imply that leadership should give room for subordinates to work on the delegated duties to enhance their motivation and performance. Lack of effective delegation could be due to lack of necessary skills by the leadership. This denies the employees the opportunity to utilize their skills and bring in new ideas necessary for effecting change.

On staff appraisals $(39.7 \%)$ disagreed that leaders allow employees to appraise their own work while (37.2\%) suggested that they do. A study on 'The Relationship between Self - and Supervisor Appraisals' byTichatonga (2002) showed that self appraisals were a better predictor of job satisfaction than supervisor appraisals. Self-appraisal as a self-development tool requires employees to think about their strengths and weaknesses and set goals for improvement. Cawley (1998) in a review study, demonstrated the positive effects of participation during the appraisal process itself including, employee input during the appraisal interview and use of employee self-assessment. The findings imply that the leadership should allow self appraisals to create greater job satisfaction and improve performance. The variation in response suggests that the leadership allows to some extent, self appraisal among the employees.

The study found out that $(37.2 \%)$ of the respondents agreed that leaders help employees accept responsibility of their work while (32.6\%) disagreed.The findings agree with studies that show that proper delegation encourages the subordinates to exercise initiative and to give wholehearted cooperation in the accomplishment of unit tasks. This also increases their desire for greater responsibilities.Is'haq (2008) reported that intellectual stimulation leadership is one that shows the degree to which the leader provides encouragement to his subordinates to be creative in looking at old problems in new ways, create an environment that is tolerant to seemingly extreme positions, and nurture people to question their own values and beliefs and those of organization. In a study bySrivastava and Bartol (2006) it was noted that an empowering leader is a supportive leader who provides guidance to followers, treats them fairly, and recognizes the value of their input. Given that team members expect to receive fair recognition by an empowering leader for their contribution of ideas and information, they are likely to be motivated to share their unique knowledge with others. Arnold, Arad, Rhoades, andDrasgow (2000) in a study on the empowering leadership questionnaire: the construction and validation of a new scale for measuring leader behaviors show that empowering leadership demonstrates a 
general regard for team members' well-being. This implies that the universities' leadership should improve on the methods adopted for duty delegation as noted by variation in the responses.

Overall, the study observed that the respondents agreed that the leadership in the universities is moderately effective as noted by $(39.78 \%)$ and $(36.26 \%)$ who disagreed. The findings agree with Ramsden's argument that good leadership can make academic work a more enjoyable and more productive experience for everyone, including the leader (Ramsden, 1998;14). It is through organized leadership that is democratic that an institution can be competitive, Kenyan Universities not an exception. Yukl (1989) argued that quality of leadership is one of the most important determinants of meeting success in a tertiary institution. University or any institution cannot be competitive without good leadership (Ramsden, 1998).

These results suggest that Kenyan public universities lack strong leadership and this is bound to affect their competitiveness negatively

Table 1.2 Leadership

\begin{tabular}{|c|c|c|c|c|c|c|c|}
\hline & & 1 & 2 & 3 & 4 & 5 & total \\
\hline 1 & $\begin{array}{l}\text { Employees are part of decision } \\
\text { making process }\end{array}$ & 19.9 & 28.7 & 18.1 & 29.4 & 3.9 & 100 \\
\hline 2 & $\begin{array}{l}\text { Leaders provide guidance without } \\
\text { pressure to the subordinates }\end{array}$ & 17.4 & 25.9 & 17.7 & 34.0 & 5.0 & 100 \\
\hline 3 & $\begin{array}{l}\text { Leaders stay out of the way of } \\
\text { subordinates as they do their work }\end{array}$ & 17.4 & 27.0 & 20.2 & 28.2 & 7.4 & 100 \\
\hline 4 & $\begin{array}{l}\text { Most workers get supportive } \\
\text { communication from their leaders }\end{array}$ & 11.0 & 22.3 & 17.7 & 42.2 & 6.7 & 100 \\
\hline 5 & $\begin{array}{l}\text { As a rule, leaders allow employees to } \\
\text { appraise their own work }\end{array}$ & 11.0 & 28.7 & 23.0 & 31.2 & 6.0 & 100 \\
\hline 6 & $\begin{array}{l}\text { Most employees do not feel insecure } \\
\text { about their work and need direction }\end{array}$ & 12.1 & 23.8 & 21.6 & 32.3 & 10.3 & 100 \\
\hline 7 & $\begin{array}{l}\text { Leaders help employees under them } \\
\text { accept responsibility for completing } \\
\text { their work }\end{array}$ & 11.0 & 21.6 & 23.8 & 36.2 & 7.4 & 100 \\
\hline 8 & $\begin{array}{l}\text { Leaders give employees complete } \\
\text { freedom to solve problems on their } \\
\text { own }\end{array}$ & 16.7 & 34.0 & 17.0 & 24.5 & 7.8 & 100 \\
\hline 9 & $\begin{array}{l}\text { It is the leaders' responsibility to } \\
\text { employees under them to help them } \\
\text { find their passion }\end{array}$ & 11.0 & 23.8 & 22.3 & 30.9 & 12.1 & 100 \\
\hline 10 & $\begin{array}{l}\text { Leaders give effective orders and } \\
\text { clarify procedures }\end{array}$ & 7.8 & 22.7 & 22.3 & 34.8 & 12.4 & 100 \\
\hline \multirow[t]{2}{*}{11} & $\begin{array}{l}\text { In general employees are given room } \\
\text { to make decisions concerning their } \\
\text { areas of work }\end{array}$ & 12.1 & 26.2 & 17.7 & 31.9 & 12.1 & 100 \\
\hline & Average & 12.37 & 23.89 & 18.7 & 29.97 & 8.01 & 100 \\
\hline
\end{tabular}

\subsection{Correlation analysis of leadership on the competitveness of the Universities}

The objective of the study sought to determine whether leadership as influenced the competitiveness of the Universities in Kenya. From fig.1.0 it is clear that there is a positive linear relationship between leadership and competitiveness of public Universities in Kenya. This concurs with findings by Ursachi who noted that leadership development plays a very important role in the process of organizational transformation that explains the shift from a competitive level to another one. Leadership is seen as "the process of influencing the activities of a person or group of people in order to achieve the organization's objectives (Ursachi, 2005).

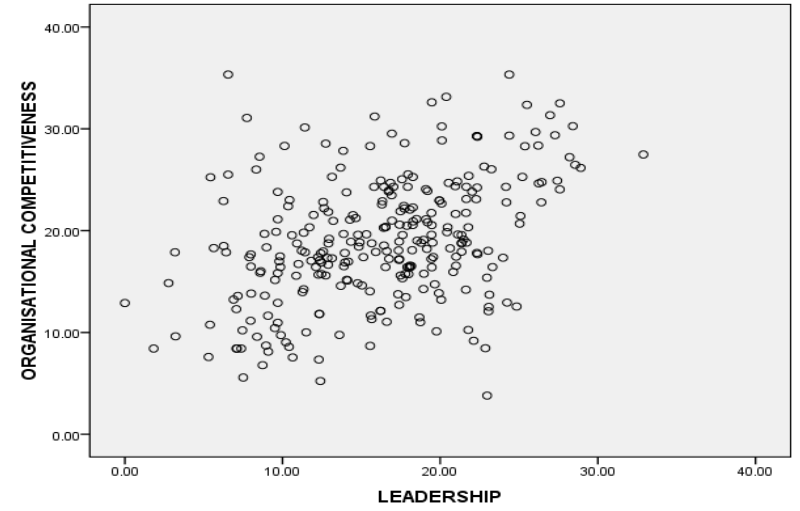

Figure 1.0 Scatter plot of the relationship between leadership and universities competitiveness 
A Pearson correlation test was performed whereby the correlation coefficient was computed. It ranges in value from -1 to +1 , indicating a perfect negative and positive linear relationship respectively between two variables. The absolute value of the correlation coefficient indicates the strength, with larger absolute values indicating stronger relationships. The finding in table 1.3 shows a positive correlation of 0.403 between leadership and competitiveness. This implies that an increase in leadership effectiveness will lead to an increase in the Universities competitiveness.

Table 1.3 Correlation between leadership and competitiveness

\begin{tabular}{llrr}
\hline & & & \\
& & $\begin{array}{c}\text { ORGANISATIONAL } \\
\text { COMPETITIVENESS }\end{array}$ & LEADERSHIP \\
\hline ORGANISATIONAL & Pearson Correlation & 1 & $.403^{* *}$ \\
COMPETITIVENESS & Sig. (2-tailed) & & .000 \\
& $\mathrm{~N}$ & 282 & 282 \\
LEADERSHIP & Pearson Correlation & $.403^{* *}$ & 1 \\
& Sig. (2-tailed) & .000 & 282 \\
& $\mathrm{~N}$ & 282 & \\
\hline
\end{tabular}

**Correlation is significant at the 0.01 level (2-tailed).

\subsection{Regression analysis of leadership on competitiveness of Universities}

A graphical illustration of the relationship between leadership and competitiveness was presented in fig 1.1 The findings of a positive relationship between leadership and competitiveness concur with those of Ramsden (1988) who found that University or any institution cannot be competitive without good leadership. Leadership influences the future level of competitiveness directly, but also indirectly - it impacts the organization's current actions, which influence the future level of competitiveness. It is therefore a very important factor - determinant of the two relationships
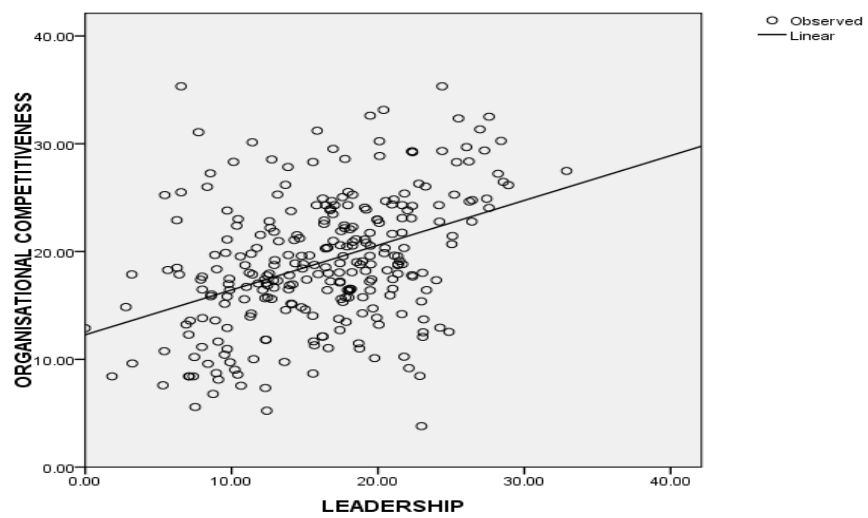

Fig 1.1 Relationship between leadership and competitiveness

Table 1.4 provides the $\mathrm{R}$ and $\mathrm{R}^{2}$ value representing the simple correlation. Conventionallya correlation greater than 0.8 is generally described as strong, whereas a correlation less than 0.5 is generally described as weak. These values can vary based upon the "type" of data being examined. A study utilizing scientific data may require a stronger correlation than a study using social science data.

The $\mathrm{R}$ value is 0.403 which indicates a weak correlation. The $\mathrm{R}^{2}$ value indicates how much of the dependent variable, "Competitiveness", can be explained by the independent variable, "Leadership". In this case, 16.2\% can be explained, which is relatively low.

Table 1.4 Model Summary for Leadership

\begin{tabular}{|c|c|c|c|c|}
\hline Model & $\mathrm{R}$ & R Square & Adjusted R Square & Std. Error of the Estimate \\
\hline 1 & $.403^{\mathrm{a}}$ & .162 & .159 & 5.58882 \\
\hline
\end{tabular}

\section{a. Predictors: (Constant), LEADERSHIP}

ANOVA results in Table 1.5 indicate that the regression model predicts the outcome variable significantly well. This indicates the statistical significance of the regression model that was applied. An F statistic of 54.261 indicated that the model was significant. This was supported by a probability value of 0.000 . This is less than the 
conventional probability of 0.0005 , which is less than 0.05 , and indicates that; overall, the model applied can statistically significantly predict the outcome variable.

\begin{tabular}{|c|c|c|c|c|c|c|}
\hline & & Sum of Squares & $\mathrm{df}$ & Mean Square & $\mathrm{F}$ & Sig. \\
\hline \multirow[t]{3}{*}{1} & Regression & 1694.836 & 1 & 1694.836 & 54.261 & $.000^{\mathrm{a}}$ \\
\hline & Residual & 8745.766 & 280 & 31.235 & & \\
\hline & Total & 10440.602 & 281 & & & \\
\hline
\end{tabular}

Table 1.6 provides the information needed to predict competitiveness from leadership. Both the constant and leadership contribute significantly to the model. The regression equation is presented as follows; Competitiveness $=12.277+0.416($ leadership $)$

$\underline{\text { Table 1.6 Coefficient determination of leadership and Competitiveness }}$

\begin{tabular}{|c|c|c|c|c|c|c|}
\hline \multicolumn{2}{|c|}{ Model } & \multicolumn{2}{|c|}{ Unstandardized Coefficients } & \multicolumn{2}{|l|}{$\begin{array}{l}\text { Standardized } \\
\text { Coefficients }\end{array}$} & \multirow{2}{*}{$\frac{\cdot}{\text { Sig }}$} \\
\hline & & B & Std. Error & Beta & $\mathrm{t}$ & \\
\hline \multirow[t]{2}{*}{1} & (Constant) & 12.277 & .971 & & 12.649 & .000 \\
\hline & LEADERSHIP & .416 & .056 & .403 & 7.366 & .000 \\
\hline
\end{tabular}

a. Dependent Variable: ORGANISATIONAL COMPETITIVENESS

\subsection{Conclusion and Recommendations}

It was also noted that leadership inthe public universities in Kenya is fairly effective. However there are several leadership aspects that require improvement. They include involving employees in decision making, delegation, employee appraisal system and offering good guidance to employees. Improved leadership will lead to a more innovative and motivated employees and ultimately improved competitiveness of the Universities. The study recommends that the leaders in Public Universities should be trained on effective leadership as a strategy of making the Institutions competitive.

\section{References}

[1]. Amabile T.M, Schatzel, E.A., Moneta, G.B., and Kramer, S.J. (2004). Leader behaviors and the work environment for creativity: Perceived leader support. The Leadership Quarterly, 15:1, 5-32.

[2]. Arnold, J.A., Arad, S., Rhoades, J.A. and Drasgow, F. (2000), "The empowering leadership questionnaire: the construction and validation of a new scale for measuring leader behaviors", Journal of Organizational Behavior, Vol. 21 No. 3, pp. 249-69

[3]. Bradley L. Kirkman and Benson Rosen (1999) Beyond Self-Management: Antecedents and Consequences of Team Empowerment. The Academy of Management Journal Vol. 42, No. 1 (Feb., 1999), pp. 58-74

[4]. Branson, C.M. (2005b), "Personal values and principalship behaviour: illustrating therelationship" paper presented at the 10th Annual Values and Leadership Conference,Penn State University, University Park, PA, 13-15 October.25

[5]. Brown, M. E., Treviño, L. K., (2005). Ethical leadership: A social learning perspective for construct development and testing. Organizational Behavior and Human Decision Processes, 92: 117-134

[6]. Cawley, B.D., Keeping, L.M. and Levy, P.E. (1998), "Participation in the performance appraisalprocess and employee reactions: a meta-analytic review of field investigations", Journal ofApplied Psychology, Vol. 83 No. 4, pp. 615-33

[7]. House, R. J., Hanges, P. J., Javidan, M., Dorfman, P. W., \& Gupta, V. (2004). Culture, leadership, and organizations:The GLOBE study of 62 societies. Journal of Cross-Cultural Psychology, 36(5), 628-630.

[8]. Ishaq, Musa (2008). Leadership qualities and organizational transformation: A case study of University of Abuja Library, Abuja. Borno Library,Archival, and Information Science Journal 7 (1): 75-79

[9]. Joseph C. Rost, "Leadership Development in the New Millennium.” The Journal of Leadership Studies“, 1993, Vol. 1, No. 1, pp. 92-110.

[10]. Lombardi, J. Craig, D. D Capaldi, E. D., \& Gater, D. S. (2002). Annual Report on The Top American Research Universities,The Center, University Organization, Governance and Competitiveness. Washington: The Lombardi Program on Measuring University Performance.

[11]. Porter, M., \& Ketels, C. (2003). Moving to the next stage. DTI Economics Paper No 3. UK competitiveness: Ramsden, P. (1998). Learning to Lead in Higher Education. London: Routledge.

[12]. Sekaran, U. (2000). Research Methods for Business- A Skill-Building Approach. New York, USA: John Wiley \& SonsSrivastava, A. and Bartol, K.M. (2006), "Empowering leadership in management teams: effects onknowledge sharing, efficacy, and performance", Academy of Management Journal, Vol. 49 No. 6,

[13]. Tichatonga J Nhundu The relationship between self and supervisor appraisal with clarity and job satisfaction Journal of Educational Administration, Vol. 30 Iss: 1.

[14]. Treviño, L.K., Hartman, L.P., Brown, M. (2000), "Moral person and moral manager: how executives develop a reputation for ethical leadership", California Management Review, Vol. 42 pp.128-42.

[15]. Ursachi, I., (2005) Management, second edition, ASE, BucharestYukl, G. (2009), "Leadership and organizational learning: an evaluative essay", LeadershipQuarterly, Vol. 20, pp. 49-53. 
[16]. Yukl, G. and Becker, W. (2006), "Effective empowerment in organizations", OrganizationManagement Journal, Vol. 3, pp. 210-31.

[17]. Yukl, G. and Fu, P.P. (1999), "Determinants of delegation and consultation by managers", Journalof Organizational Behavior, Vol. 20, pp. 219-32.

[18]. Yukl, G., Gordon, A. and Taber, T. (2002), "A hierarchical taxonomy of leadership behavior:integrating a half century of behavior research", Journal of Leadership and Organization.

[19]. Zhang, X. and Bartol, K. (2010), "Linking empowering leadership and employee creativity:the influence of psychological empowerment, intrinsic motivation, and creativeengagement process", Academy of Management Journal, Vol. 53, pp. 107-28. 